\title{
Editorial de Per Musi 31
}

Nesse número 31, a revista Per Musi, qualificada com o QUALIS A1 na CAPES e indexada na base SciELO, traz 15 artigos e 2 resenhas. Começa aqui uma nova fase da revista, cuja editoração em XML permitirá uma inserção internacional, disponibilização e recuperação de informações muito maiores e, quiçá num futuro próximo, a utilização de links conectando os artigos a arquivos de áudio e vídeo. Além disso, como passa a ser exclusivamente online, Per Musi permite que os autores utilizem ilustrações coloridas.

Em sua análise da obra Expressão Anímica para piano solo, de 1979, Iracele Vera Livero de Souza expõe procedimentos de indeterminação desenvolvidos pela compositora Eunice Katunda. O exame de aberturas diante do tempo, duração, altura ou efeitos instrumentais, bem como das formas de escritura coextensivas - exata, indicativa ou, ainda, através de gráficos -, contribui não só ao conhecimento mais amplo da música brasileira do século $X X$, mas também à fundamentação da performance instrumental.

Fernando Chaib, João Catalão e Homero Chaib Filho apresentam, em dois artigos consecutivos, um estudo sobre a influência do gesto do percussionista nas sensações de continuidade, suspensão e conclusão de um dado trecho musical. No primeiro deles, os autores fornecem dados adquiridos e analisados a partir dos pesos percentuais, ao passo que o segundo artigo se apoia na técnica estatística AFC - Análise Fatorial de Correspondências. Dentro da complexa relação estabelecida em grande parte do repertório entre a materialidade do percussionista e o texto musical, busca-se entender até que ponto o corpo pode ser um agente auxiliador no processo de transmissão de sensações específicas sobre a música em uma performance.

Ênio Lopes Mello, Luiz Ricardo Basso Ballestero e Marta Assumpção de Andrada e Silva investem numa abordagem largamente interdisciplinar, num cruzamento semiológico entre fisioterapia, fonoaudiologia, medicina, psicologia, filosofia, tendo sempre como bússola as relações entre signos posturais/vocais e a autoimagem na prática do canto lírico. A expressão e a imagem corporal seriam ali figuradas por meio da conscientização da postura e do movimento. Na verdade, expressão e imagem corporal se retroalimentariam numa cadeia performática.

A colaboração igualmente interdisciplinar entre Marcelo Parizzi Marques Fonseca, Francisco Cardoso e Antônio Guimarães traz ao público um estudo da relação entre postura corporal e performance musical, tendo a flauta como foco específico. Aspectos centrais da biomecânica da postura como o centro de gravidade corporal, a musculatura da estática e a postura normal em pé e sentada aparecem como parâmetros de alterações que devem ser conscientizadas pelo instrumentista, tendo em vista a qualidade da execução e a longevidade de sua carreira.

Rodrigo Bueno Ferreira, Henry Maas, Luiz Cesar Savi, Thiago Corrêa de Freitas e Aloísio Leoni Schmid problematizam a escolha de materiais para a confecção de flautas transversais renascentistas. A partir de uma descrição da história desses instrumentos, sua utilização, suas formas de execução e, principalmente, de sua construção, relativizam a seleção de materiais tradicionais na determinação da qualidade do instrumento, ao mesmo tempo em que demonstram madeiras brasileiras, como a imbuia e a sucupira, como matéria prima empiricamente testada. 
Andréa Cristina Cirino se debruça sobre o tema da aprendizagem musical na maturidade, tendo como interlocutores alunos do curso de extensão universitária Apreciação e Musicalização na Maturidade - UFMG, com idade a partir de 50 anos. A autora põe em evidência a necessidade de adequação dos métodos de aprendizagem musical específicos ao público alvo, conjugando teoria básica e atividades práticas segundo as possibilidades e a experiência prévia do aprendiz.

Diante da dificuldade em se estabelecer critérios objetivos para a avaliação do desempenho de um instrumentista, os portugueses Maria Clara Costa e Jaime Filipe Barbosa contrastam a avaliação livre de um grupo de professores de trompete e uma segunda avaliação, inspirada na Teoria Espiral de Desenvolvimento Musical de Swanwick. A comparação entre as duas abordagens aponta para uma limitação da primeira, onde prevalecem apenas duas dimensões da crítica musical - materiais e expressão - nível mais básico dentro da Teoria Espiral.

Ângela Maria Ferrari e Felipe Avellar de Aquino observam como o compositor alemão Max Reger emprega modelos de J.S. Bach na construção de sua Suíte $N^{0} 1$, Op. 131c para violoncelo solo. De fato, além de combinar elementos da harmonia do final do século XIX com técnicas contrapontísticas bachianas, o romantismo tardio de Reger se inspira mesmo na escolha de tonalidades ou em transformações e expansões de motivos caros ao universo bachiano. Paralelamente à análise estilística inerente, a abordagem dos autores fornece preciosos subsídios interpretativos.

Nahim Marun trata de alguns dilemas interpretativos decorrentes da diversidade editorial na música para piano de Frédéric Chopin (1810-1849). A ampla divulgação das suas primeiras edições na internet, juntamente com as possibilidades de performance trazidas pelas pesquisas históricas, expandiram as referências estabelecidas para sua música e trouxeram mais flexibilidade interpretativa a alguns parâmetros musicais, como direções fraseológicas, escolhas das articulações, timbre instrumental, dedilhados, pedais, rubati e ornamentações.

Em sua análise do Prelúdio $n^{\circ} 3$ para violão solo de Heitor Villa-Lobos, Daniel Ribeiro Medeiros fornece chaves de interpretação fundamentadas na performance historicamente informada e na intuição informada. Ambas intuição e percepção musical são, nesse estudo de caso, reforçadas por aspectos estéticos e estilísticos.

Fabio Scarduelli e Carlos Fernando Fiorini esboçam um panorama dos percursos de técnica e repertório empregados nos cursos de violão "clássico" das universidades públicas (estaduais e federais) brasileiras. Para tal, os autores submeteram um questionário respondido por docentes de $94 \%$ dessas instituições. O material elaborado se oferece como ferramenta para reflexão em torno da pedagogia de formação e do perfil dos bacharéis em violão.

A partir da observação de movimentos culturais junto a populações baianas e, principalmente, soteropolitanas social e economicamente excluídas, Armando Alexandre Castro e Maria Teresa Franco Ribeiro apontam para o potencial de transformação propriamente política da música. Seguindo pistas teóricas deixadas pela geografia crítica ou a ecologia dos saberes, os autores lançam mão não somente de dados estatísticos oficiais sobre Salvador, mas incluem ainda dados de pesquisa de campo pessoal. $\mathrm{O}$ trabalho traz à tona um conjunto considerável de instituições para as quais a música é um vetor estético-pedagógico relevante na transformação social dos cidadãos, no contexto de uma cidade que, distante dos discursos turísticos, apresenta consideráveis índices de pobreza, concentração de renda e desigualdade socioeconômica. 
Jane Maria de Medeiros e Lucília Regina de Souza Machado abordam os fatores existentes e aqueles que ainda deveriam ser moldados para que a rica produção musical belo-horizontina permitisse a elaboração de sua proposta de um Sistema Produtivo e Inovativo Local (SPIL). Tal sistema seria sustentado por um processo social, econômico e político capaz de catalisar essas energias e potencialidades musicais, transformando-as em força motriz de uma estratégia de desenvolvimento local. Nesse processo, as autoras defendem que a cultura seja reconhecida como investimento, e não despesa, com foco no investimento nos valores, na criatividade, na imagem da cidade (no estado, no país e no exterior) e na geração de emprego, renda e inclusão socioeconômica.

Seguindo uma retrospectiva histórica e de contextualização da pesquisa empírica sobre o planejamento da performance instrumental, Luís Cláudio Barros estabelece o panorama das principais vertentes temáticas examinadas pela pesquisa científica. Ciente de que o objeto de estudo possui muitas ramificações, abordagens e especificidades, propõe que grande parte dos temas de pesquisa possa ser enquadrada dentro de algumas categorias temáticas de maior abrangência.

lara Luzia Rodriguez trata da prática músico-teatral na Espanha do início do século XVIII, com foco no estudo da zarzuela Acis y Galatea. A autora demonstra, assim, como o teatro foi utilizado pela dinastia Bourbon para fazer sua propaganda política, incorporando elementos da tradição espanhola, bem como da ópera italiana.

Rosângela Pereira de Tugny busca se aproximar do discurso de especialistas ameríndios sobre a origem não autoral de suas músicas, onde a escuta ocupa a função de produção. Busca também compreender as limitações dos artistas ocidentais quando tentam colaborar com as formas de trabalho acústico operantes entre estes coletivos. À luz de reflexões de Bruno Latour e Jacques Rancière em torno de temas relacionados às políticas da estética, às noções de "produção" e às fissuras construídas pelas sociedades modernas entre noções de natureza e cultura, a autora toma o percurso do compositor francês Pierre Boulez como forma de problematizar um encontro da produção artística musical dos círculos de compositores de salas de concerto com as cosmosonologias ameríndias.

Na Seção de Resenhas - Pega na Chaleira, Débora Andrade apresenta o livro Ampliando o repertório do coro infanto-juvenil: um estudo de repertório inserido em uma nova estética, de Leila Rosa Gonçalves Vertamatti. Já Verônica Oliveira da Silva e Léslie Piccolotto Ferreira trazem uma leitura do livro Alemão para Cantores, de Barbara Schilling Tengarrinha, que trata da dicção e articulação da voz na música.

Finalmente, Informamos que Per Musi está disponível gratuitamente nos sites www.scielo.com.br e www.musica.ufmg.br/permusi. As versões impressas de quase todos os números da revista até o número 30 ainda podem ser adquiridas através do e-mail permusi@ufmg.br.

Fausto Borém

Fundador e Editor Científico de Per Musi

\section{Eduardo Rosse}

Editor Científico Assistente de Per Musi 